only be ascertained by reference to the narrative of the cruises.

The last forty pages contain an instalment of the biological work accomplished on the cruises. The subjects treated are :-Fishes, by Mr. E. W. L. Holt and Mr. L. W. Byrne; Amphipods and Isopods, with descriptions of two new species, by Mr. W. M. Tattersall; and Pyrosoma spinosum, by Mr. G. P. Farran.

The printing, illustrations, and get-up of the book are excellent, and a few misprints and obscurities, chiefly in the earlier pages, do not seriously detract from the value of Dr. Wolfenden's contribution to oceanography. It is to be hoped that we soon may have a second volume dealing further with the large amount of biological material which must have been amassed.

\section{THE CASE FOR EUGENICS.}

The Family and the Nation: a Study in Natural Inheritance and Social Responsibility. By W. C. Dampier Whetham, F.R.S., and Catherine Durning Whetham. P. viii +233. (London: Longmans, Green and Co., I9o9.) Price $7 s, 6 d$. net.

"T THE power of heredity," writes Mr. Whetham, 1 " is an old story; 'family likeness,' 'family characteristics,' ' family temper,' are expressions which convey ideas well known to all men. Yet with amazing inconsistency we have taken little if any account of such knowledge in our conduct, little if any in our theories of social and political life. We have talked and acted as though it were of no account how men were bred, or what classes of the community were reproducing themselves fastest and what declining in number, as long as each individual was enabled by improved conditions to pass his brief lifetime in increased comfort and security."

It is the duty of preachers of eugenics, a duty conscientiously undertaken by the author, to end this state of affairs; to teach our future statesmen what biological factors govern the rise and fall of nations, and to educate public opinion in such a way that, aided by the legislation that will then be possible, it will insist on the more rapid multiplication of the desirable components in our society, and aim at the elimination of the rotten parts which now permeate it. Mr. Whetham's book cannot fail to influence all who read it. He writes with the clearness and vigour which flow from conviction based on clear thinking; and thus, having the facts with him, presents a strong case strongly.

The line of argument adopted is as follows. First, the importance of heredity is insisted on, and the methods by which it is being studied scientifically are described, namely, the analytical method initiated by Mendel and developed by Prof. Bateson and others, and the statistical method originated by Sir Francis Galton and extended by Prof. Karl Pearson.

Many pedigrees are given as instances of inheritance in man, and are illustrated by diagrams like those published in the "Treasury of Human Inheritance," now being produced by the Galton Laboratory. The important question of the relative influence of heredity and environment is referred to, but since there is very little evidence available for discussion, it necessarily receives but scanty treatment. As the author points out, the only quantitative study of the subject yet published is the work of Barrington and Pearson on lieenness of vision and defects of eyesight. They found that no measurable relation exists between powers of vision and environment, whereas the influence of heredity is well marked.

Two chapters follow, the one on the inheritance of mental defect, and the other on the inheritance of ability, the latter being based largely on Sir Francis Galton's "Hereditary Genius." The influence of heredity is further shown in an examination of the circumstances causing the rise, fall, or extinction of families, and finally the effect of heredity acting in conjunction with a differential birth-rate is treated very fully.

It is a well-known fact that the birth-rate in Great Britain fell from $3^{6}$ per 1000 in 1876 to 27 per 1000 in I907. This in itself may give cause for alarm, but the most serious feature of the fall is that it has not been the same in all classes. If the lowest stratum of society had been affected equally with the higher strata, the 27 per Iooo would have been reduced to a much lower figure. As it is, the lowest stratum is as prolific as before, therefore our birth-rate has become selective. The least valuable portions of the population are selected to contribute a disproportionately large share of the next generation, by the action of the more valuable portions in bringing about at any rate a partial self-elimination.

The author gives historical instances, in which the action of a selective birth-rate produced by various causes has influenced the rise and fall of nations. As an example we may quote the influence of the Dominican and Franciscan monks, of whom the former came to England in 1220 , the latter in 1224. Through their preaching and persuasion, the majority of our men of intellect were drawn into the monasteries and thus rendered sterile. Roger Bacon, Adam Marsh, Robert Grosseteste, Dun Scotus, and Occham are but a few names from a host of others. As a result came the stagnation of the fourteenth and fifteenth centuries, which was only ended by the overthrow of the monasteries in the time of Henry VIII. Then followed the "glories of the Elizabethan age," and "a period of scientific and literary activity, which carried England on through the seventeenth century."

In conclusion, we may heartily recommend this book to those who are interested in the study of heredity as affecting human societies. It is no disparagement to say that the arguments used have many points in common with the teaching of Prof. Karl Pearson. To him, as well as to Sir Francis Galton, all those who write on eugenics must owe a debt.

E. H. J. S.

\section{INDIAN WOODS AND THEIR USES.}

Indian Woods and their Uses. By R. S. Troup. Pp. $273+$ ccxviii. (Calcutta : Government Printing Office, 1909.) Price $4 s$.

THIS work is the outcome of a gradual development of research on the part of the Indian Forest Department. The foundation of the system now instituted was laid in $188_{3}$, when Dr. (now 